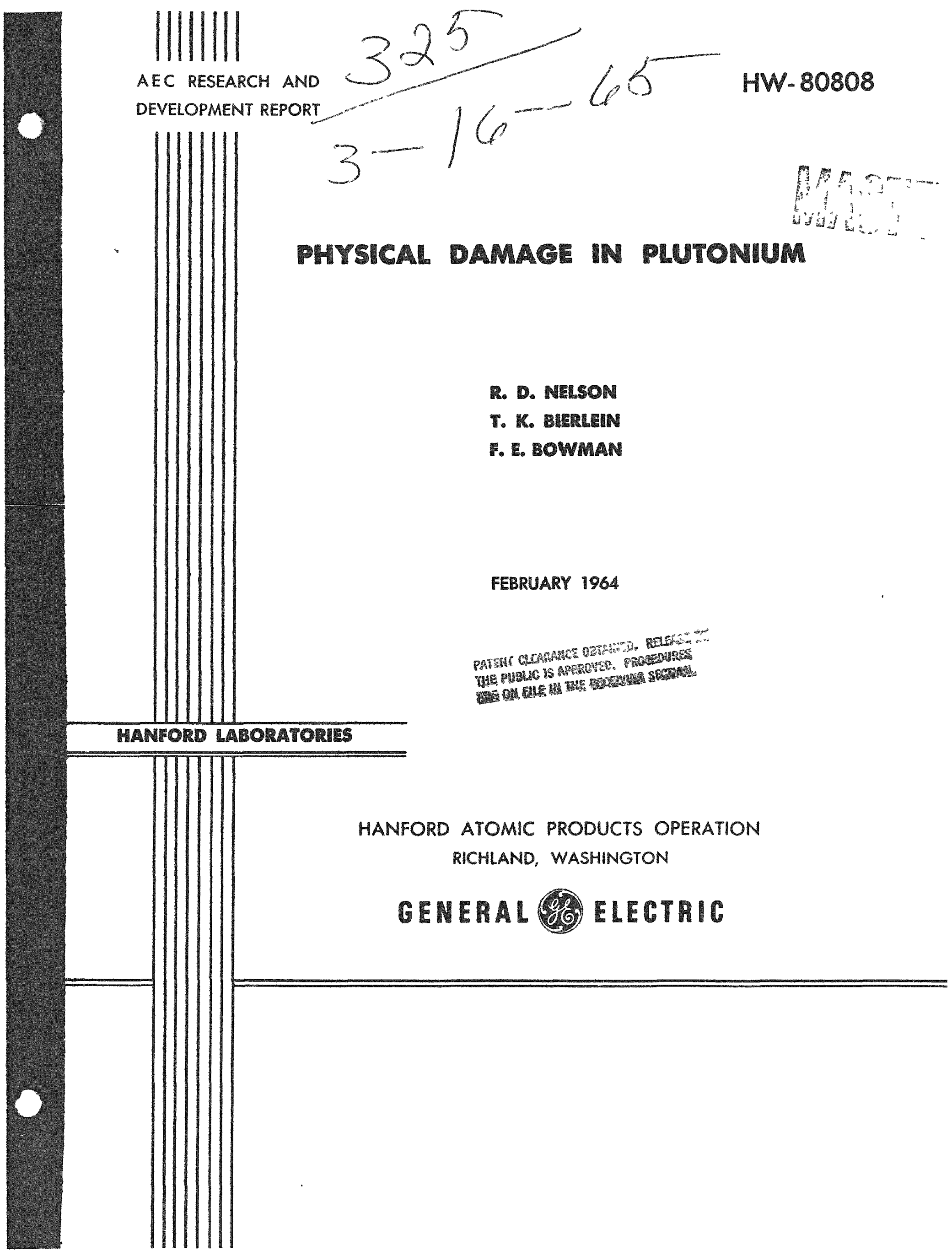




$$
\begin{gathered}
\text { HW-80808 } \\
\text { UC-25, Metals, Ceramics, } \\
\text { and Materials } \\
\text { (TID-4500, 34th Ed.) }
\end{gathered}
$$

\title{
PHYSICAL DAMAGE IN PLUTONIUM
}

By

$$
\begin{aligned}
& \text { R. D. Nelson } \\
& T \cdot K \cdot \text { Bierlein } \\
& \text { F. E. Bowman }
\end{aligned}
$$

\author{
Metallurgy Research \\ Reactor and Fuels Laboratory
}

Hanford Laboratories

February 1964

\section{HANFORD ATOMIC PRODUCTS OPERATION RICHLAND, WASHINGTON}

Work performed under Contract No. AT(45-1)-1350 between the Atomic Energy Commission and General Electric Company

Printed by/for the U. S. Atomic Energy Commission 


\section{DISCLAIMER}

This report was prepared as an account of work sponsored by an agency of the United States Government. Neither the United States Government nor any agency Thereof, nor any of their employees, makes any warranty, express or implied, or assumes any legal liability or responsibility for the accuracy, completeness, or usefulness of any information, apparatus, product, or process disclosed, or represents that its use would not infringe privately owned rights. Reference herein to any specific commercial product, process, or service by trade name, trademark, manufacturer, or otherwise does not necessarily constitute or imply its endorsement, recommendation, or favoring by the United States Government or any agency thereof. The views and opinions of authors expressed herein do not necessarily state or reflect those of the United States Government or any agency thereof. 


\section{DISCLAIMER}

Portions of this document may be illegible in electronic image products. Images are produced from the best available original document. 


\section{PHYSICAL DAMAGE IN PLUTONIUM}

\section{INTRODUCTION}

When plutonium is transformed from beta to alpha, it sustains extensive physical damage as indicated by cracks. These cracks can be either microcracks or macrocracks depending upon the previous mechanical and thermal history of the metal. The most significant variables that influence the amount, size, and distribution of these cracks are the temperature of the $a \rightarrow \alpha$ transformation, the metal quality, the specimen size and shape, and the number of previous $3 \rightarrow \alpha$ transformations.

The physical damage in plutonium after repeated $\beta \rightarrow \alpha$ transformations may be quitepronounced. $(1,2,3)$ Large macrocracks, or even fracture of the metal, may occur, however, after only one $3 \rightarrow a$ trans formation. Coffinberry and Waldron (4) reported that in early work at Los Alamos thermal cycling of plutonium between phases resulted in a progressive decrease in density and increase in surface distortion similar to that found in uranium subjected to transformation cycling. It has been suggested that the microcracks formed primarily during the $v \rightarrow B$ trans formation because this was the first transformation between two complex crystal structures on cooling from elevated temperatures. $(4,5)$

This report presents some additional experimental work and observations on physical damage in plutonium. The occurrence and extent of this damage has been evaluated largely on the basis of optical metallographic observations and precision density determinations. SUMMARY AND CONCLUSIONS

High quality as-cast plutonium may contain a large volume of microcracks that have formed during the $3 \rightarrow \alpha$ transformation. The volume of microcracks increases with increasing transformation temperature, higher metal purity, increased specimen size, and after $\alpha \rightleftarrows 3$ thermal cycling. 
Thermal cycling produces growth in all directions, general distortion, and extensive surface rumpling. Plutonium containing no microcracks can be produced by quenching from the beta phase to $-75 \mathrm{C}$ during casting. No physical damage has been observed in metal that initially contains no microcracks after either $v \rightleftarrows B, \delta \rightleftarrows v$, or $\delta \rightleftarrows 3$ thermal cycling.

\section{MICROCRACKING IN AS-CAST PLUTONIUIM}

Metallography and ultrasonic testing reveal that as-cast plutonium may contain a large volume of microcracks. The volume of these microcracks varies from less than $0.1 \%$ to as high as $2 \%$ of the total specimen volume depending upon the impurity content and the rate of $\beta \rightarrow \alpha$ trans formation. Metal containing less than $200 \mathrm{ppm}$ total impurities of which less than 100 ppm are delta stabilizers, such as aluminum, gallium, and americium, that is cooled through the $B \rightarrow \alpha$ transformation at 1 to $20 \mathrm{C} / \mathrm{min}$ will contain a distribution of microcracks similar to that revealed by the microstructure in Figure 1. These microcracks form predominantly at the final alpha grain boundaries as indicated in Figure 2.

The size, distribution, and concentration of microcracks generally vary considerably within a given piece of metal. The dependency of microcracks on the $3 \rightarrow a$ transformation rate and impurity level is discussed in greater detail in the section on thermal cycling damage. In general, a higher $3 \rightarrow \alpha$ transformation temperature and higher purity will result in more extensive microcracking.

The microcracking appears to occur after the $\beta \rightarrow \alpha$ transformation is 50 to $60 \%$ complete. Loasby and Lowe ${ }^{(5)}$ have plotted the percent of void formation against the percent of beta that has transformed into alpha and obtained a linear relationship in the range 50 and 100\% beta transformed. Nelson ${ }^{(3)}$ found this relationship to be as shown in Figure 3 . The deviation depends upon such factors as specimen size, isothermal transformation temperature, and impurity content. 
The volume associated with microcracks in as cast plutonium is decreased only slightly by hydrostatic compression at 6000 atmospheres at a temperature of $90 \mathrm{C}$, which is within the alpha phase stability range. Accordingly, the metal density increases only slightly, 0 to $0.05 \mathrm{~g} / \mathrm{cm}^{3}$. The major portion of the observed density change is the volume decrease due to transformation of retained phases. Hydrostatic pressing at the same pressure but at $180 \mathrm{C}$ followed by slow cooling to the alpha phase underpressure results in larger density increases, $0.10 \mathrm{~g} / \mathrm{cm}^{3}$ or more. The amount of increase depends upon the temperature of pressing and the extent of microcracks, inclusions, and other imperfections in the metal. If microcracks comprise $1 \%$ of the volume of metal and they are eliminated during compression, the density will increase $0.2 \mathrm{~g} / \mathrm{cm}^{3}$. Densities up to $19.80 \mathrm{~g} / \mathrm{cm}^{3}$ at $25 \mathrm{C}$ have been obtained. Microcracks are not discernible at $250 \mathrm{X}$ after this treatment.

The slight density increase of high quality plutonium after pressing at $90 \mathrm{C}$ is attributed primarily to transformation of a small amount of retained beta phase and not to decreasing the volume of microcracks. The density increase after pressing at $180 \mathrm{C}$ is due primarily to decreasing the volume of microcracks and only a small percentage results from transformation of retained phases. The volume decrease associated with the trnasformation of retalned phases is the same in elther pressing operation: however, in bera pressing the volume decrease associated with compressing the microcracks is much greater than in alpha pressing. The amount of density increasebrought about by pressing depends upon the previous history of the metal.

PHYSICAL DAMAGE AFTER REPEATED a $\overrightarrow{2}$ TRANSFORMATIONS

Repeated $x \rightleftarrows 3$ transformations result in an increase in the extent of internal micro-and macrocracking. The size of the cracks increases progressively with continued thermal cycling (Figure 4). The extent of thermal cycling damage depends upon the metal quality, sample size, and $2 \rightleftarrows \sim$ transformation temperature during thermal cycling. 
Plutonium that is thermally cycled through the $\mathbb{a}^{2} \rightarrow \infty$ transiormation by heating and cooling at $2 \mathrm{C} / \mathrm{min}$ may form voids up to $3 \%$ per cycle $\left(0.6 \mathrm{~g} / \mathrm{cm}^{3}\right.$ density decrease per cycle), resulting in growth, general distortion, and extensive surface rumpling (Figure 5). Growth is always observed in both the radial and longitudinal directions. Occasionally one to four very slow $2-a$ transformations are sufficient to cause fracture of a specimen Densities of certain specimens have decreased from 19.7 to $6 \mathrm{~g} / \mathrm{cm}^{3}$ after 100 thermal cycles.

Heating plutonium into one of the high temperature phases and cooling very slowly into the alpha phase region will cause macrocracks and even fracture after only one transformation cycle Heating into the epsilon phase region and slow cooling produces the most damage. For example, a high purity plutonium specimen, $1 \mathrm{~cm}$ in diameter and $1 \mathrm{~cm}$ long that had been epsilon heat-treated at $600 \mathrm{C}$, cooled to $95 \mathrm{C}$ at $10 \mathrm{C} / \mathrm{hr}$ and then cooled to $60 \mathrm{C}$ at $1 \mathrm{C} / \mathrm{hr}$ contained a macrocrack $1 / 2 \mathrm{~cm}$ long and $1 / 16 \mathrm{~cm}$ wide. The cooling rate was changed at $95 \mathrm{C}$ to permit a very slow $B \rightarrow \alpha$ transformation. The $Q \Rightarrow a$ transformation was presumed complete at $60 \mathrm{C}$.

The physical damage is greater for metal transformed from the beta phase at high alpha temperatures, e.g., $70 \mathrm{C}$, than at subzero temperatures. Samples from the same melt were allowed to transform isothermally to the alpha phase at $-80 \mathrm{C},-23 \mathrm{C}, 25 \mathrm{C}, 60 \mathrm{C}$, and $73 \mathrm{C}$ after beta heat treating $30 \mathrm{~min}$ at $180 \mathrm{C}$ Each specimen was allowed to transform at the appropriate alpha temperature until apparent completion of the transformation was observed. The densities after each transformation were then determined at room temperature (Figure 6).

After the first cycle, the decreases in density of the specimens transformed isothermally at -23 and $-80 \mathrm{C}$ were essentially identical, $0.12 \mathrm{~g} / \mathrm{cm}^{3}$. This density decrease was due to both the retention of the lower density beta and the development of microcracks in the specimens. Further cycling to six cycles in the subzero range resulted in a very small density change and hence very little physical damage. Increasing the transformation 
temperature above -23 C resulted in more extensive physical damage and less retained beta. The amount of damage was greatest in the metal transformed at $73 \mathrm{C}$ with the density decrease being $0.40 \mathrm{~g} / \mathrm{cm}^{3}$ per aycle. The amount of damage was slightly less, $0.30 \mathrm{~g} / \mathrm{cm}^{3}$ per cycle in the spec1men transformed at $60 \mathrm{C}$.

Plutonium rods $1 \mathrm{~cm}$ diameter or less that do not initially contain microcracks will not form microcracks upon repeated $\alpha=3$ transformations by direct quenching from the beta phase to subzero temperatures. Micro cracks intially present within the metal, however, will be enlarged by such thermal cycling treatment. For many studies, such as elevated temperature creep. It is particularly advantageous to have sound metal. Plutonium is therefore quenched from the beta phase to a subzero temperature to provide a crack-free specimen. Plutonium metal quenched in this manner has a very fine-grained microstructure and is extremely brittle.

The following experiment and results verify the previous general1zations. Microcracks were formed in plutonium rods during the casting process by permitting the beta to transform to alpha slowly (high alpha remperatures). Such rods containing microcracks were thermally cycled 17 times by direct quenching into the beta phase at $180 \mathrm{C}$ and into the alpha phase at a subzero temperature of $-80 \mathrm{C}$. Such $\alpha \rightarrow \beta \rightarrow \alpha$ cycling $\mathrm{s}$ as followed by cycling within the alpha phase $(100 \mathrm{C}$ to $-80 \mathrm{C})$ to transform any retained phase present to alpha. The rods were $1 \mathrm{~cm}$ long and $1 \mathrm{~cm}$ in diameter. That the $\alpha \rightarrow 3 \rightarrow \alpha$ thermal eycling enlarged microcracks $w a s$ confirmed by metallography and density measurements. Plutonium trat was quencked from the beta phase during castung to avoid formation of microcracks and then thermaliy cycled in the same manner sustained no microcracking and therefore lass physical damage. The microstructure and the density of the rods after the thormai cycling treatments were essentially the same as before the cycling treatments. The pertinent data from these experiments are shown in Table $\mathrm{I}$. 
HW -80808

\section{TABLE I}

EFFECT OF $\alpha \neq 2$ TRANSFORMATION CYCLING

$(-80 \rightleftarrows+180$ C) ON THE DENSITY OF PLUTONIUM

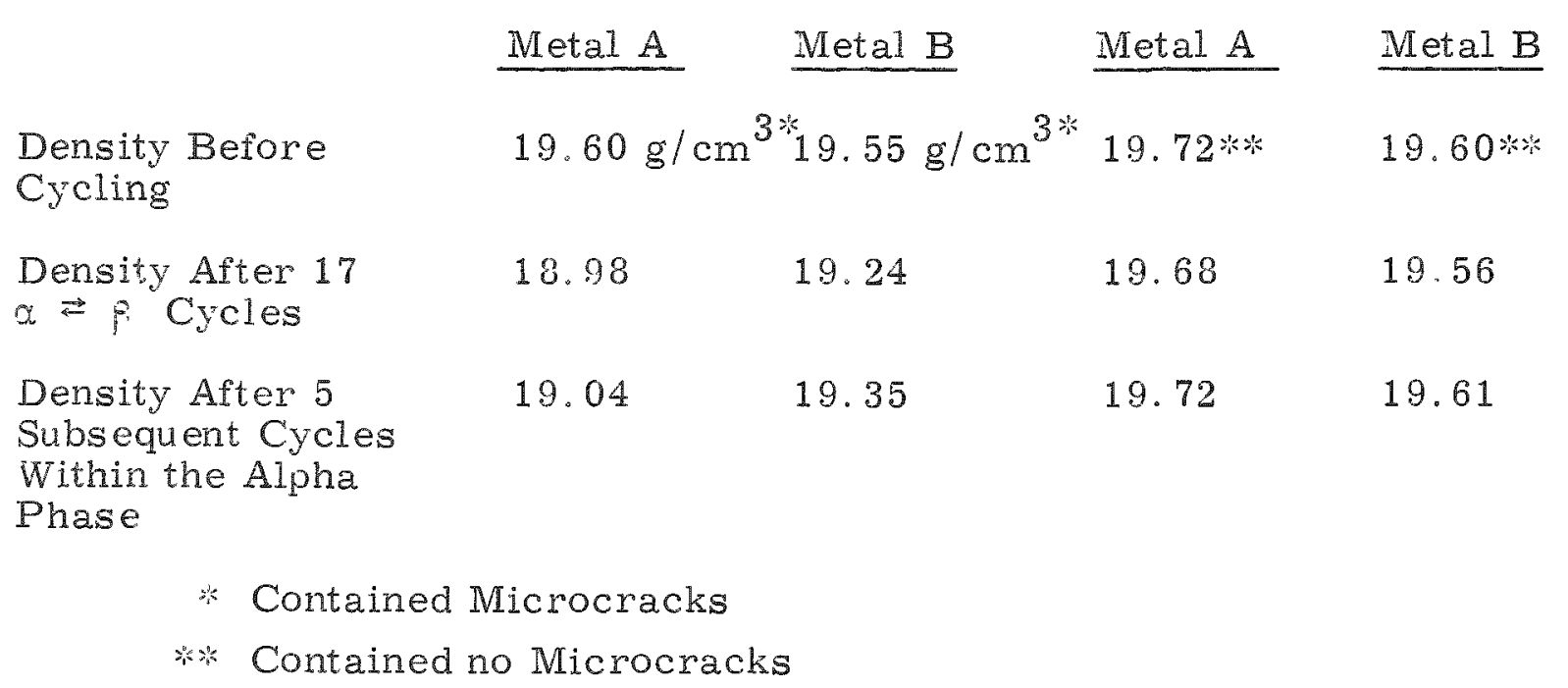

The temperature dependence of physical damage in cylindrical $1 \mathrm{~cm}$ rod specimens is presented in Figure 7. The data were obtained by two methods First, the percent microcracking per cycle was determined from the average slope of the curves between Cycles 2 and 6 in Figure 6 . Second, the density change $w$ as observed in metal that had been beta-pressed after casting, transformed to alpha under pressure, beta heat-treated $30 \mathrm{~min}$ at $160 \mathrm{C}$, quenched and isothermally transformed to alpha at different temperatures, and then finally thermally cycled between $-75 \mathrm{C}$ and $100 \mathrm{C}$ to transform retained beta to alpha A schematic of this procedure is shown in Figure 8 .

Although microcracking in high purity plutonium is pronounced at high alpha transformation temperatures, the amount of retained phases in metal cycled between the beta phase and the high alpha temperatures is quite small. The retention of beta, how ever, is quite significant below room temperature, particularly during the first cycle. 
The voids and microcracks, after repeated $\alpha \rightleftarrows Q$ transformations, are somewhat uniformly distributed throughout specimens, but large macrocracks have been observed at or near the center of specimens. For example. spheres approximately $11 / 2 \mathrm{in.}$. 1 diameter, thermally cycled at $2 \mathrm{C} / \mathrm{min}$ between 175 and $25 \mathrm{C}$ contained voids 1 to $11 / 2 \mathrm{~cm}$ in diameter at the center. Large macrocracks have also been observed at the center of thermally-cycled rods.

Increasing the specimen size generally incresses the amount of vold formation (Figure 9). However, $1 / 4$ in. diameter rods have been shown to have nearly as large a density decrease as 1 in. diameter rods when thermally cycled at a rate of $2 \mathrm{C} / \mathrm{min}$. Similar data have been obtained for spheres of varying diameter. This indicates specimen size is not as important as the metal quality or the $\beta \rightarrow \alpha$ transformation conditions at this slow transformation rate.

The effect of specimen size on microcracking increases with increasing transformation rate. The amount of microcracking is not great at subzero temperatures in small specimens, but rods or spheres greater than $11 / 2$ in. diameter will readily fracture when quenched from the beta phase to subzero temperatures where the $3 \rightarrow \alpha$ transformation rate is a maximum. This is due to large temperature differences within the metal Which lead to the formation of the more dense and less ductile alpha phase at the exterior of the specimens, while the interior consists of the lower density beta phase that subsequently transforms and contracts away from the alpha. This leads to fracture.

The physical damage associated with thermal cycling between the beta and alpha phases depends upon the amount and type of impurities present in the metal. Elements such as iron and nickel, which have little solubility in solid plutonium, and elements such as aluminum, which have extensive solubility in the delta phase mitigate the cyclic thermal damage. Some 
eiements such as carbon may possibly enhance microcracking; however, no detailed in"estigation of this has been performed. Nickel or iron in the amount of 1000 ppm decrease the amount of microcracks to $1 / 4$ that of unalloyed pluronium containing less than $250 \mathrm{ppm}$ total impurities. Addition of 600 ppm aluminum decreases the amount of physical damage to $1 / 10$ that of the same unalloyed plutonium. However, this amount of aluminum significanty increases the amount of the retained delta and beta phases. PHYSICAL DAMAGE AFTER $\alpha \approx \vee$ CXCLING

The physical damage associated with thermal cycling between the gamma and alpha phases increases with decreasing $\gamma \rightarrow \alpha$ transformation temperature as revealed by density measurements, Figure 10. This temperature dependence is in the reverse direction but the absolute magnitude is no: as great as after repated $3 \rightarrow \alpha$ thermal transformation. However, the change in transformation rate between $-75 \mathrm{C}$ and $+73 \mathrm{C}$ of the $\gamma \rightarrow \alpha$ transformation is not as great as that for the $B \rightarrow \alpha$ transformation. This semperature interval is where the gamma phase transforms directly to the alphe phase. Fr scture generally occurs after the first few cycles during either $\delta \Rightarrow a$ or $v \rightleftarrows \alpha$ cyoling in which the quenching medium is at $-75 \mathrm{C}$. The fracture results from the targe volume changes between phases. These volume changes are approximately 25 and $15 \%$ respectively.

The physical damage at temperatures where the gamma phase first :ransforms to the beta phase and then to alpha has not been measured, but is quite lange. The least amount of damage occurs when the gamma phase ransiorms to the bera phase and the metal Is then quenched to subzero temperature.

PHYSICAI DAMAGE AFTER $v \rightleftarrows \beta, \delta \rightleftarrows v$. AND $\delta \rightleftarrows 3$ CYCLING

No physical damage has been observed during the $v \rightleftarrows 3, \delta \rightleftarrows \gamma$. or $s \rightleftarrows 3$ thermal cycling in metal that initially contains no microcracks. Any microcracking that is initzally present in the metal will be enhanced by these transfromations. However, a $0.08 \mathrm{~g} / \mathrm{cm}^{3}$ density decrease has been 
observed after the first $\delta \rightleftarrows v$ cycle. This can be attributed to a retention of a small percentage of the delta phase at $190 \mathrm{C}$. A comparison of the physical damage associated with $\delta \rightleftarrows \gamma \rightleftarrows \beta \rightleftarrows \alpha$ thermal cycling as revealed by density measurements is given in Figure 11. The data were obtained from metal that had been cooled only to the beta phase during casting. This metal supposedly contained no microcracks initially. Similar data were obtained from plutonium which had initially been hydrostatically pressed at $180 \mathrm{C}$ and cooled under pressure.

ACKNOWLEDGMENTS

Thanks are extended to A. G. Graybeal, R. S. Hagan, and A. S. Cole for their assistance in performing the experimental work. 


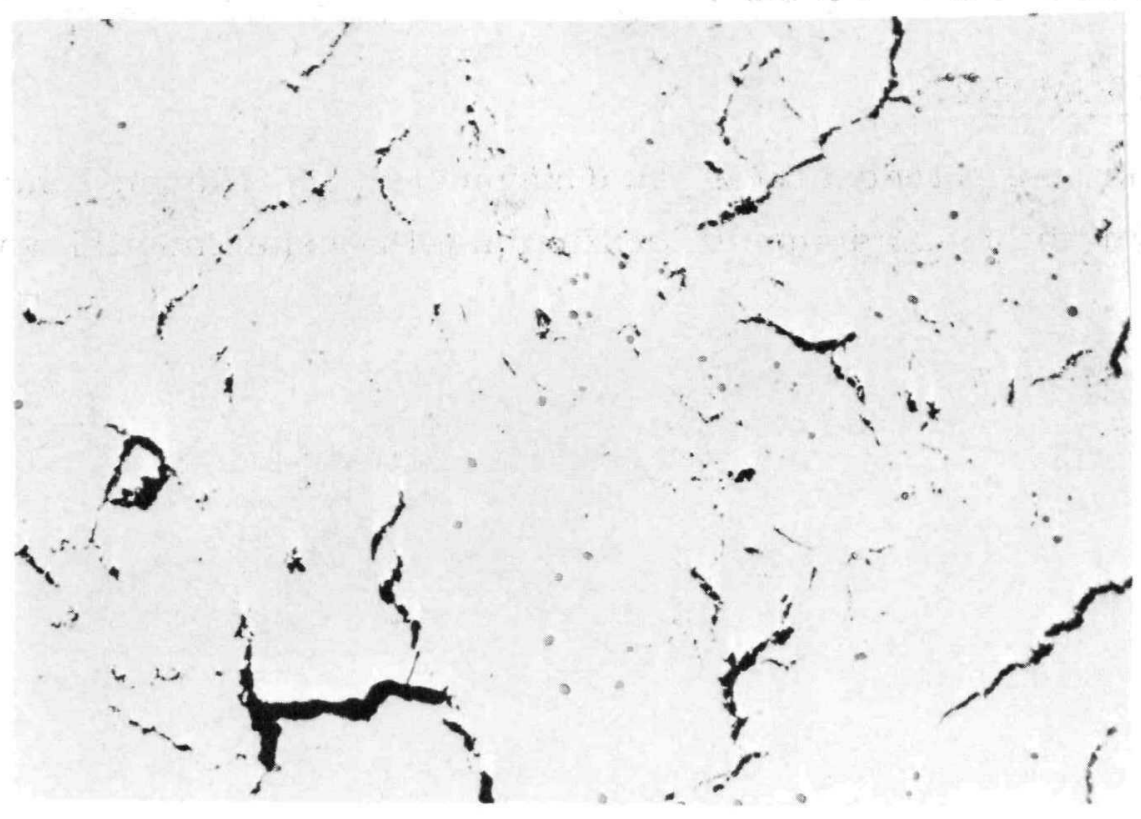

Negative No. 4-3310

\section{FIGURE 1}

Microcracks in Electrorefined Plutonium

Small Inclusions are $\mathrm{PuO}_{2}$.

As-Polished, 100X 


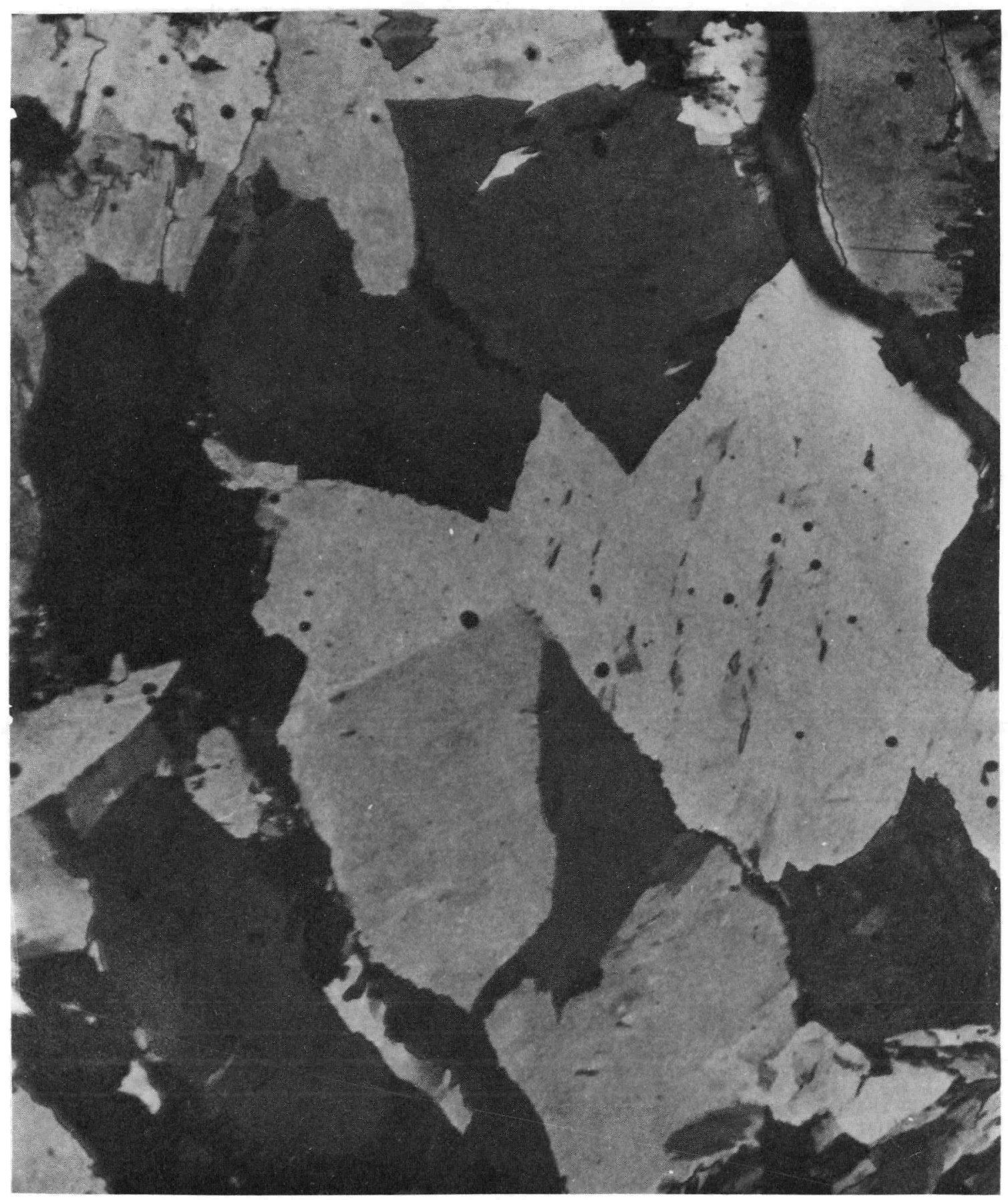

\section{FIGURE 2}

Microstructure of Electrorefined Plutonium Showing Microcracks at the Grain Boundaries Polarized Light Illumination, 200X 


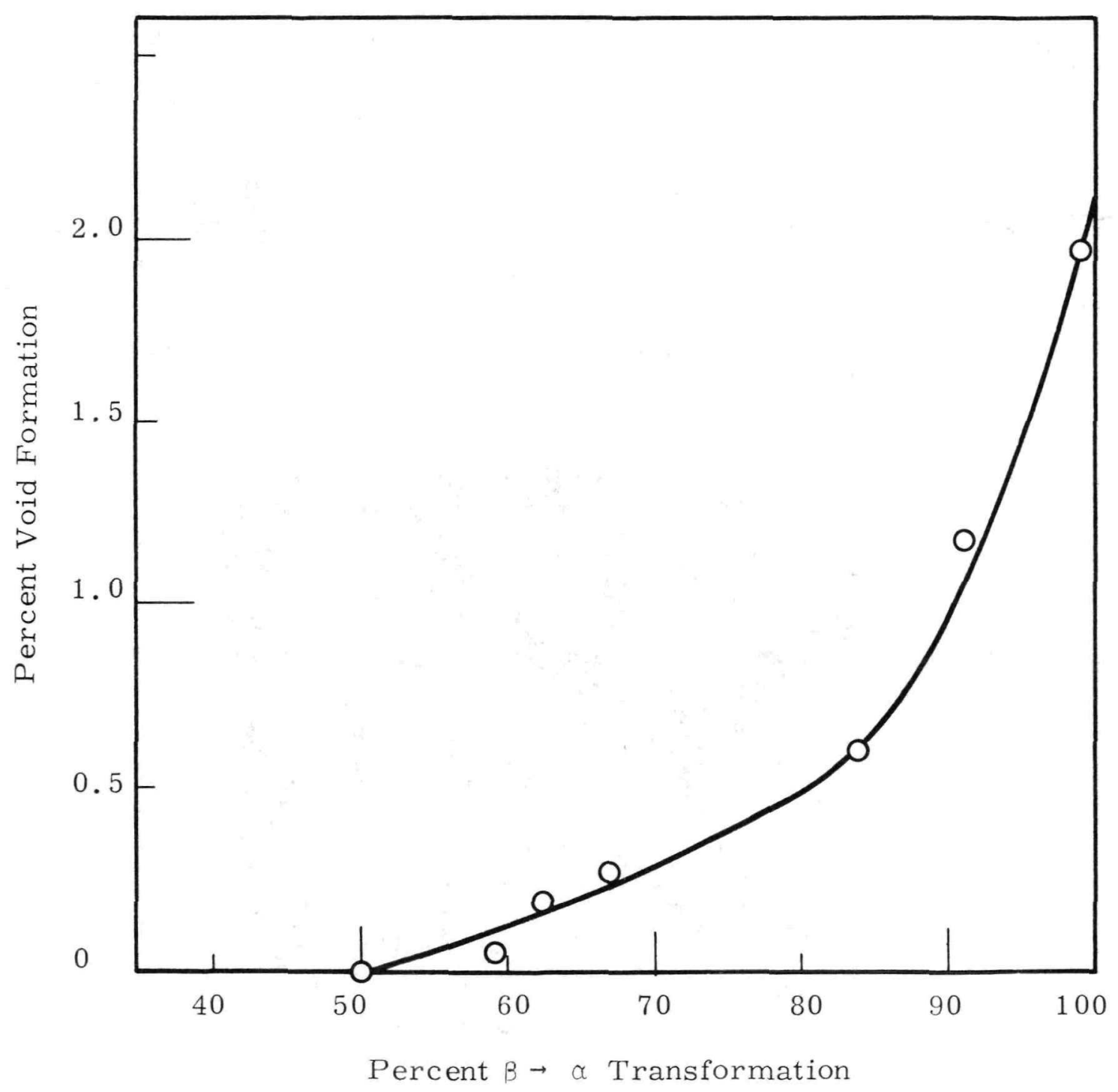

FIGURE 3

Void Formation as a Function of $\% \beta \rightarrow \alpha$ Transformation at $73 \mathrm{C}$ 


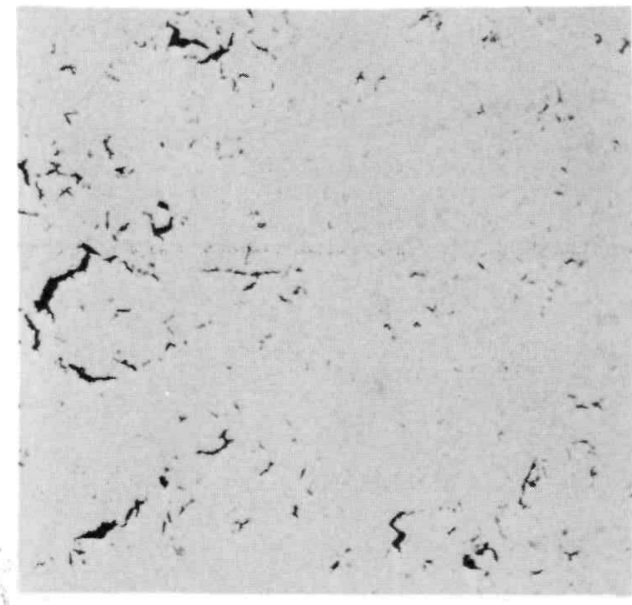

One $\alpha \rightleftarrows \beta$ Transformation Cycle

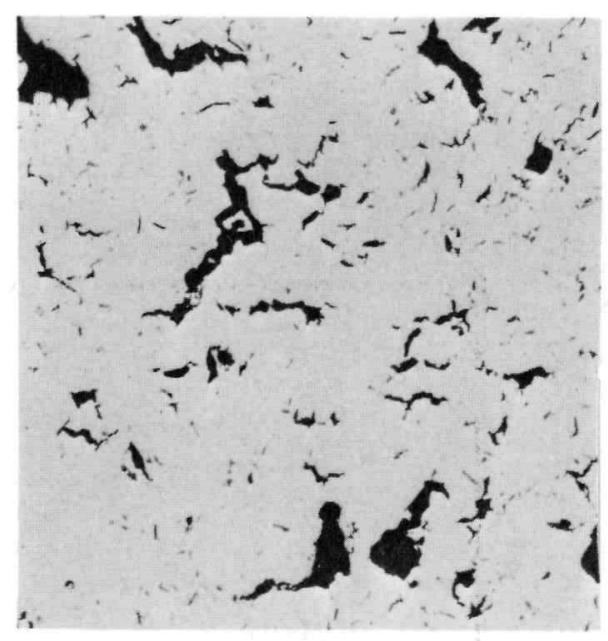

Two $\alpha \rightleftarrows \beta$ Transformation Cycles

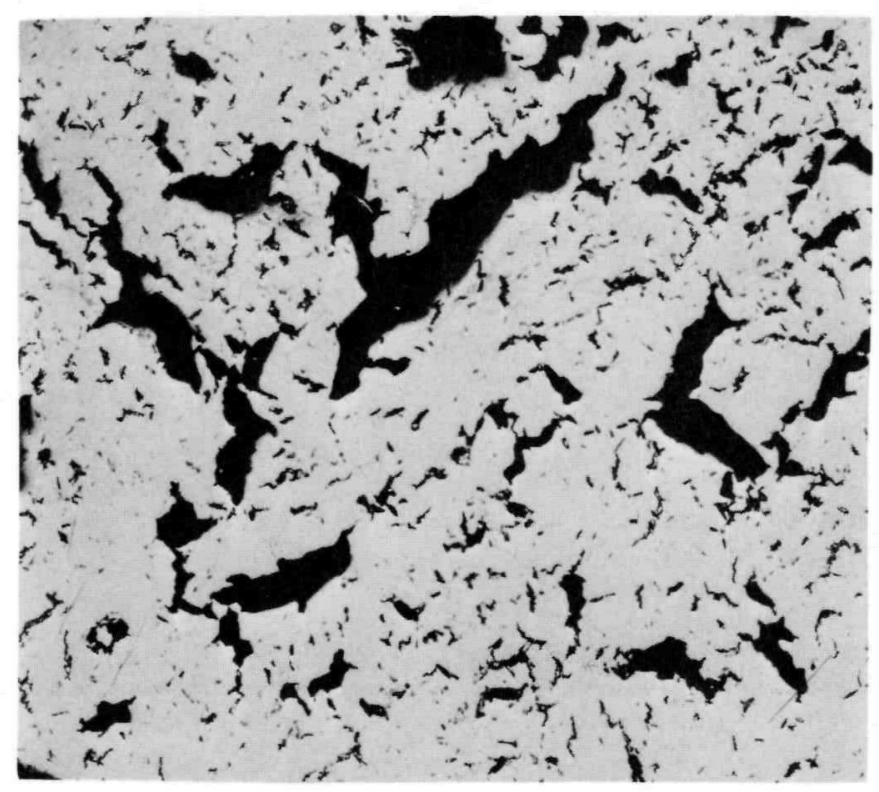

$$
\text { Four } \alpha \geq \underset{\text { Cycles }}{\beta \text { Transformation }}
$$

\section{FIGURE 4}

Representative Photomicrographs

Showing Microcracking in Plutonium

Cycled Between the Beta and Alpha Phases 50X 


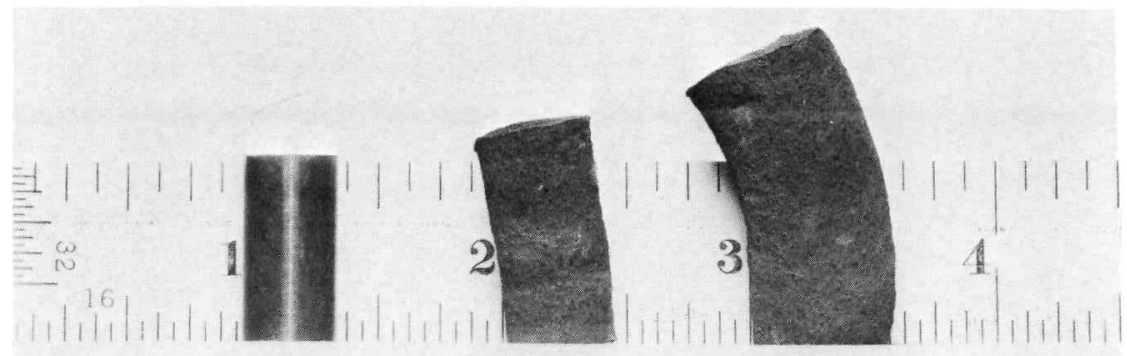

(a)

(b)

(c)

FIGURE 5

Plutonium Rods Thermally Cycled Between $180 \mathrm{C}$ (beta phase) and Room Temperature (alpha phase) at an Approximate Rate of $2 \mathrm{C} / \mathrm{min}$.
a) No Cycling
b) 50 Cycles
c) 100 Cycles

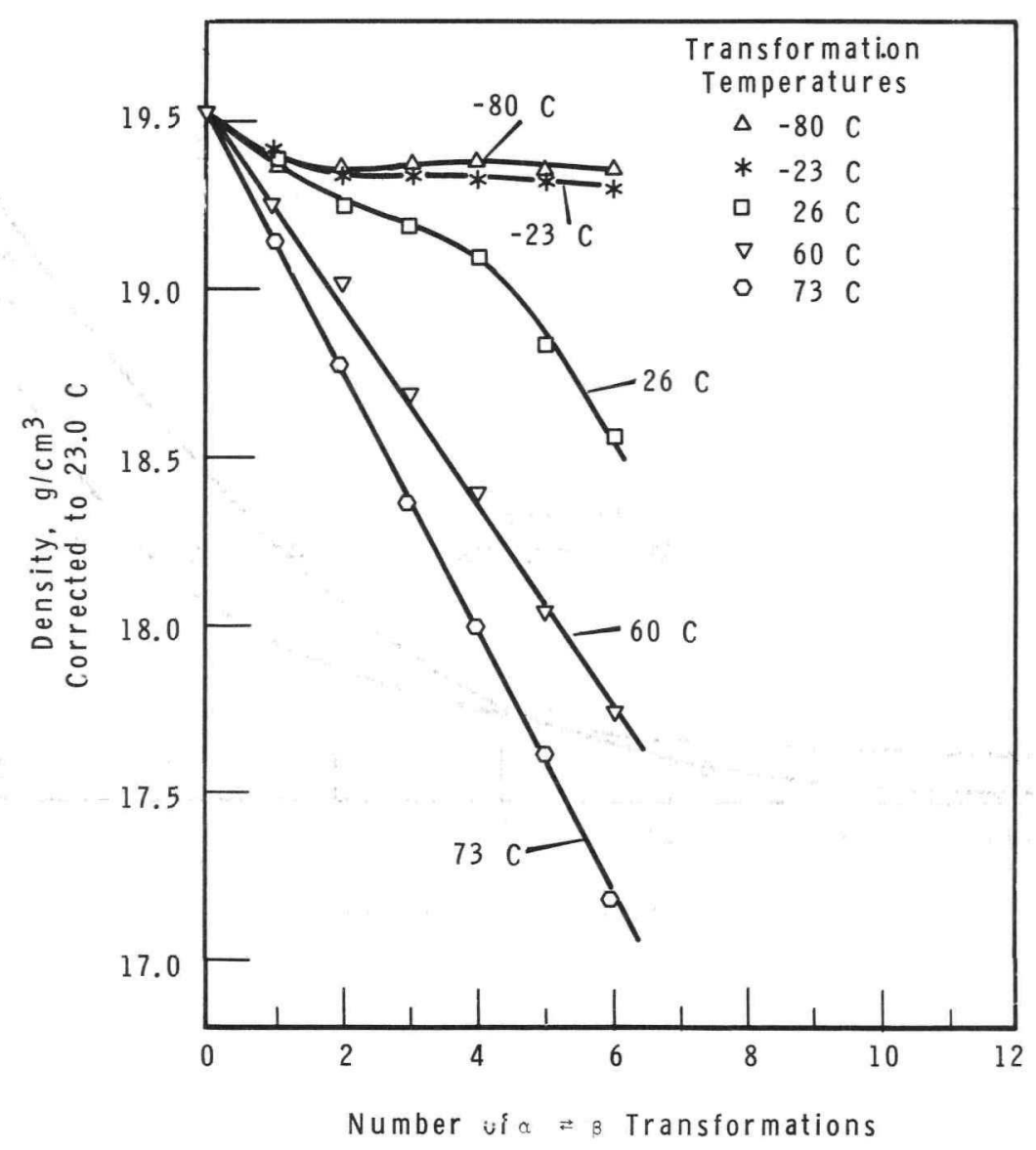

\section{FIGURE 6 \\ Alpha $\rightleftarrows$ Beta Transformation Damage}




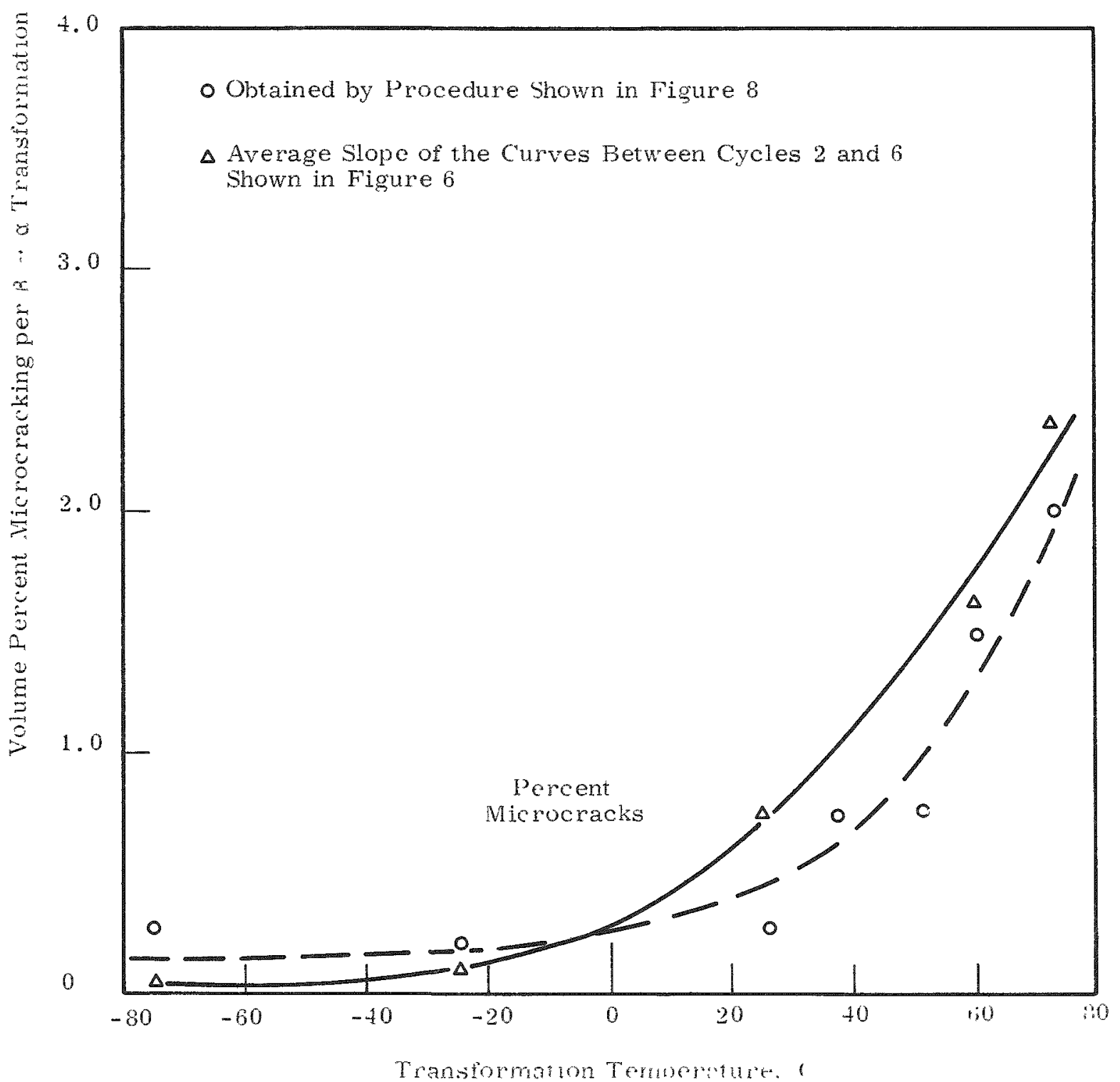

\section{FIGURE 7}

Microcracking in Plutonium as a Function of the Transformation Temperature 


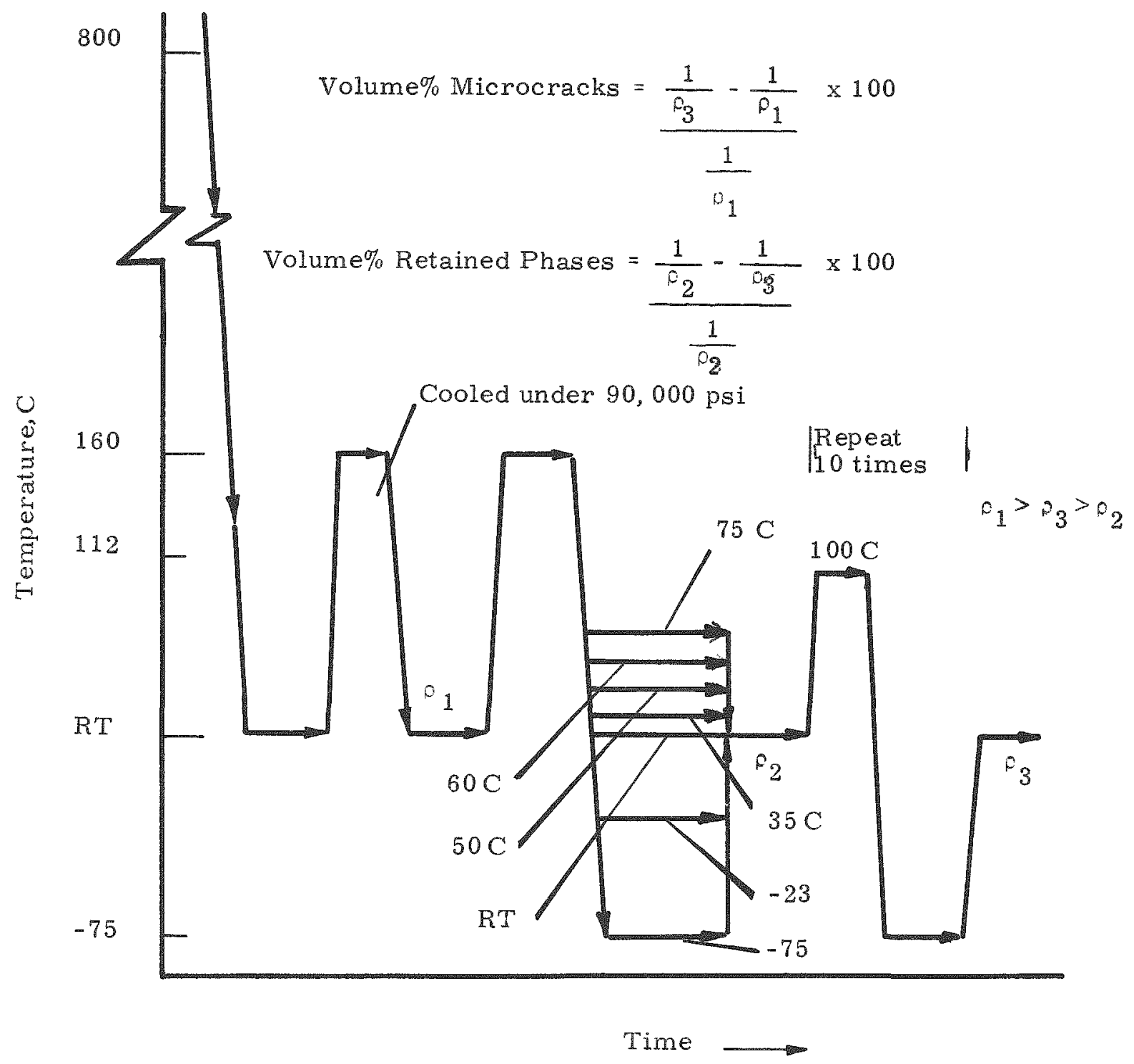

\section{FIGURE 8}

Schematic Diagram

Showing the Procedure for Determining the vol\% of Microcracks and Retained Phases in a Specimen by Density Measurements 


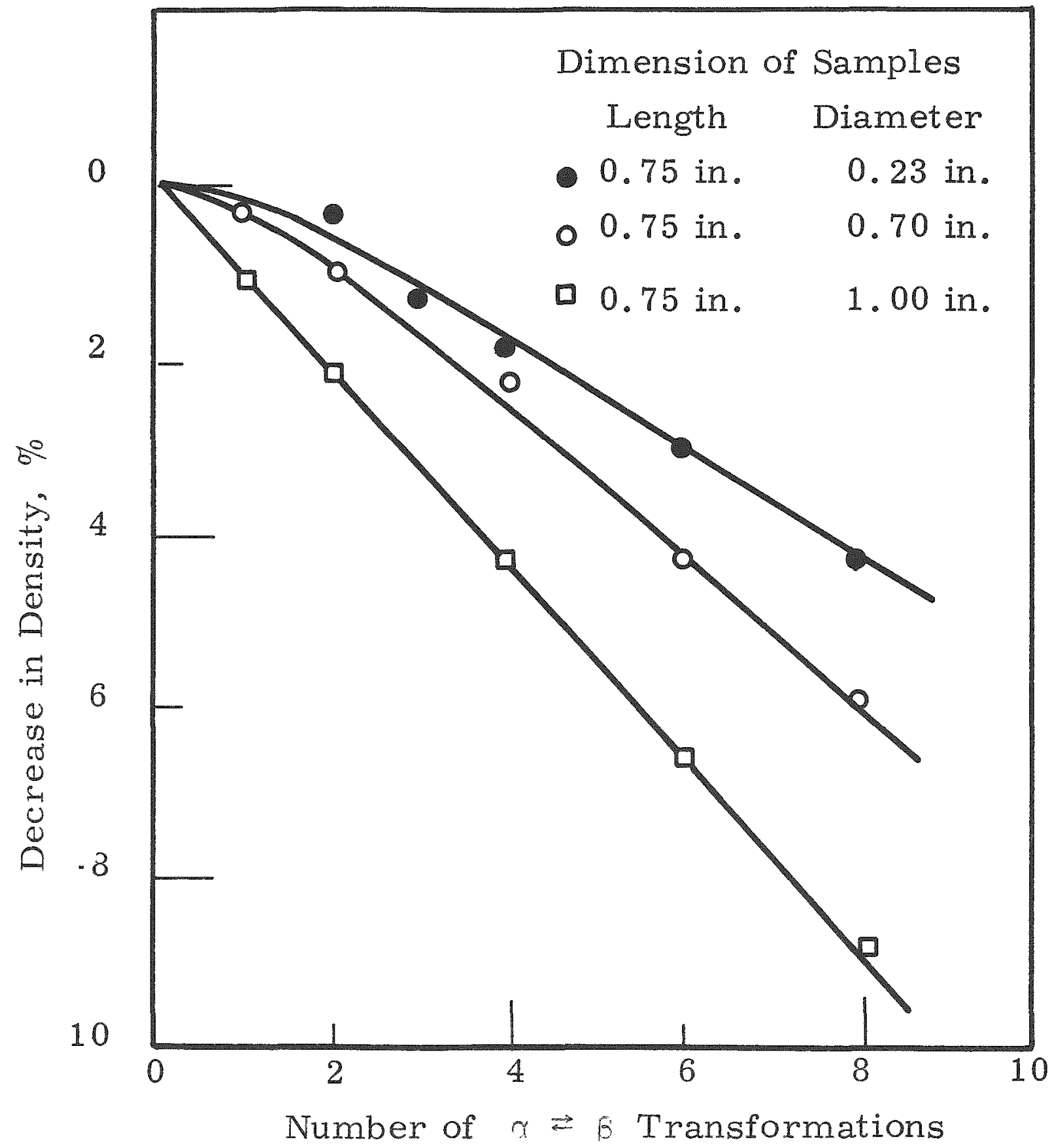

FIGURE 9

Effect of Specimen Size on Density Decrease of Plutonium when Thermally Cycled Through $\vec{\rightarrow} \rightarrow \sim$ Transformation at a Cooling Rate of $2 \mathrm{Co} / \mathrm{min}$ 
Alpha $\rightleftarrows$ Gamma Transformation Damage

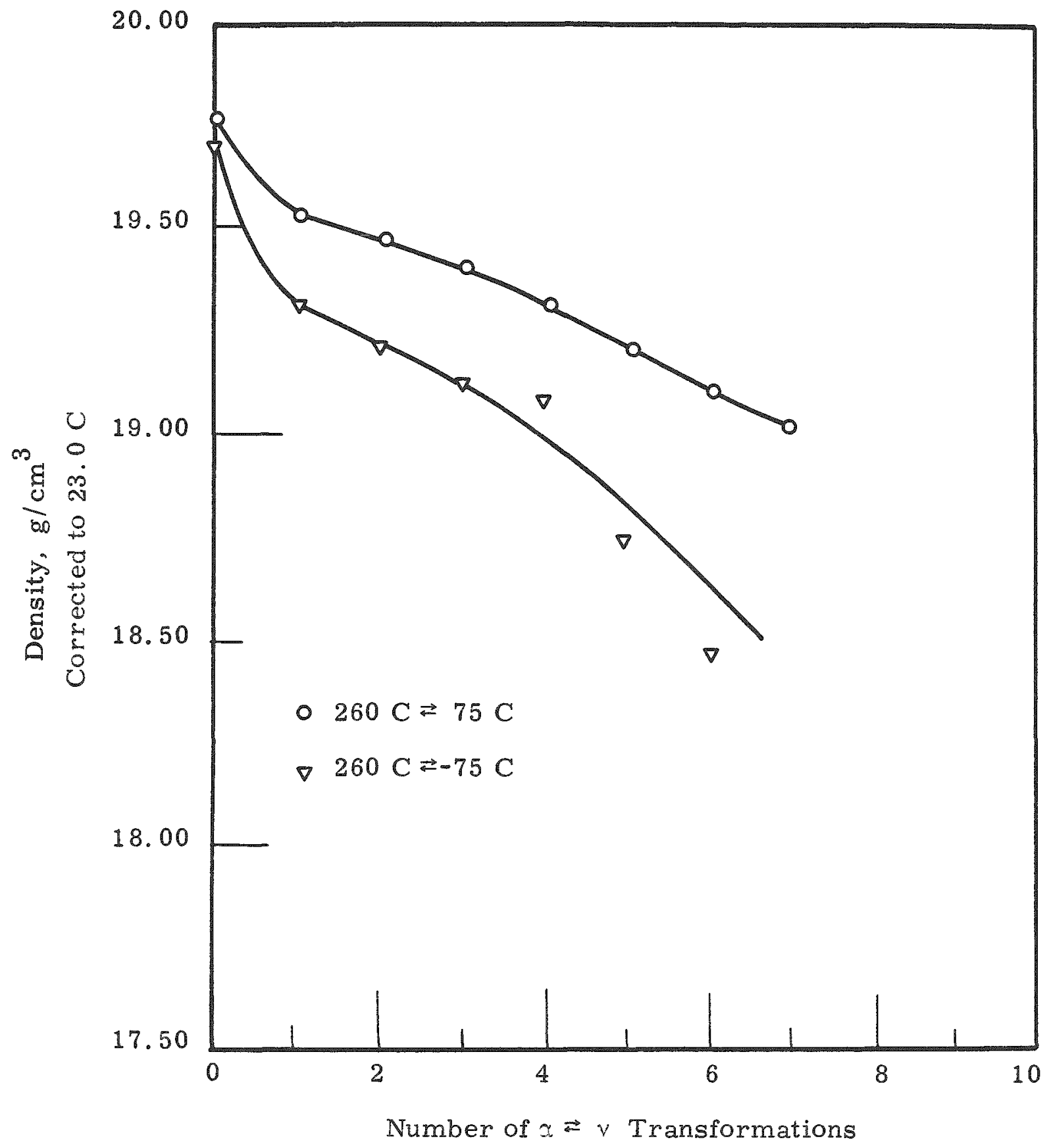

$$
\text { Alpha } \Rightarrow \frac{\text { FIGURE } 10}{\text { Gamma Cyclic Damage }}
$$




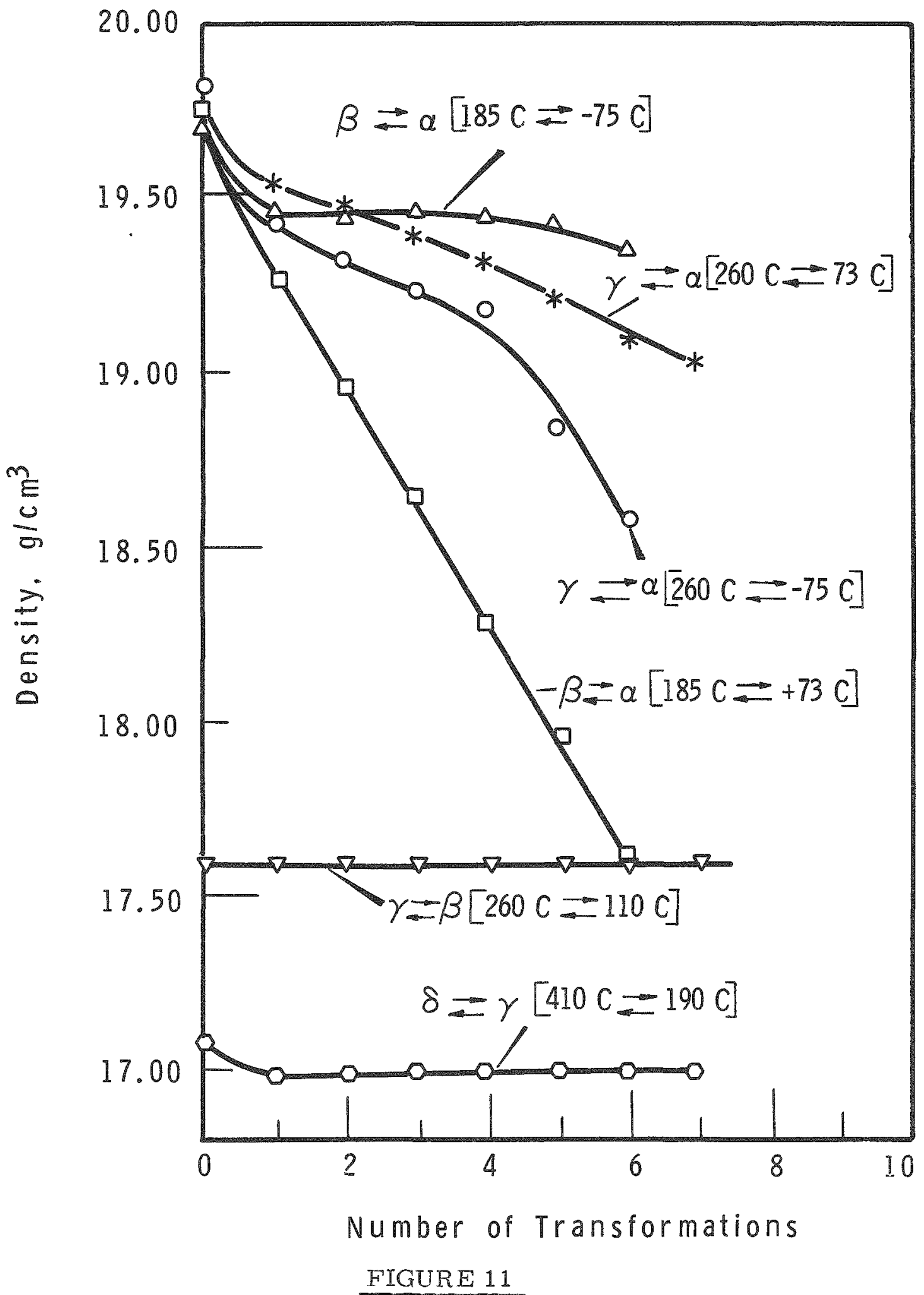

Physical Damage in Plutonium Due to Phase Transformation Cycling AEC.GE RICHLAND, WASH 


\section{REFERENCES}

1. R. D. Nelson and I. D. Thomas. "Transformation Kinetics of Plutonium, "Proceedings of the Second United Nations International Conference on the Peaceful Uses of Atomic Energy, Geneva. vol. 6. pp. 170-173. New York: United Nations, 1958.

2. R. D。 Nelson. Thermal Cycling of Plutonium, Part I, "Observations of the Physical Damage Resulting from Thermal Cycling Plutonium Through its Low Temperature Phase Transformations, "HW-61681. September 16, 1959.

3. R. D. Nelson. Transformation Kinetics of Plutonium, Part III, HW-70859. December 1961.

4. A. S. Coffinberry and M. B. Waldron. "A Review of the Physical Metallurgy of Plutonium, "pp. 354-410. Progress in Nuclear Energy, vol. 1 series v. New York: McGraw-Hill Book Company. 1956.

5. A. S. Coffinberry, F.W. Schonfeld, J.T. Waber, L.R. Kelman, and C. R. Tipton, Jr. Reactor Handbook, 2nd ed., vol. 1. "Plutonium and its Alloys," pp. 248-290. New York: Interscience Publishers, Inc., 1960.

6. R. G. Loasby and J. N. Lowe. "Kinetics of the $3 \rightarrow$ a Transformation in Plutonium, "Plutonium 1960, pp. 3-16. London: Cleaver-Humes Press Ltd. 1961 
INTERNAL DISTRIBUTION

Copy Number

\begin{tabular}{|c|c|}
\hline 1 & F.W. Albaugh \\
\hline 2 & A. E. Barber \\
\hline 3 & T. K. Bierlein \\
\hline 4 & F.E. Bowman \\
\hline 5 & L. I. Brecke \\
\hline 6 & J. L. Brimhall \\
\hline 7 & J. J. Cadwell \\
\hline 8 & R. L. Dillon \\
\hline 9 & R. E. Falkoski \\
\hline 10 & M. D. Freshley \\
\hline 11 & H.R. Gardner \\
\hline 12 & W. J. Gartin \\
\hline 13 & S. M. Gill \\
\hline 14 & G. P. Hanneman \\
\hline 15 & W. S. Hartnett \\
\hline 16 & D. D. Hays \\
\hline 17 & R. B. Hershey \\
\hline 18 & H. H. Hopkins \\
\hline 19 & Y. B. Katayama \\
\hline 20 & $R$, R。 King \\
\hline 21 & $\mathrm{H} . \mathrm{E} . \mathrm{Kissinger}$ \\
\hline 22 & L. M. Knights \\
\hline 23 & J.J. Laidler \\
\hline 24 & R. D. Leggett \\
\hline 25 & B. Mastel \\
\hline $26-55$ & R. D. Nelson \\
\hline 56 & T. C. Nelson \\
\hline 57 & G. C. Oberg \\
\hline 58 & J.G.Pace \\
\hline 59 & C. S. Powers \\
\hline 60 & A. E. Smith \\
\hline 61 & R. W. Stewart \\
\hline 62 & J.M. Taylor \\
\hline 63 & I. N. Taylor \\
\hline 64 & J.C. Tobin \\
\hline 65 & R. E. Tomlinson \\
\hline 66 & R. E. Van der Cook \\
\hline 67 & M. T. Walling, Jr。 \\
\hline 68 & C.M. Walker \\
\hline 69 & W. B. Weihermiller \\
\hline 70 & O.J. Wick \\
\hline 71 & R. G. Wheeler \\
\hline 72 & Record Center \\
\hline 73 & 300 File \\
\hline $74-81$ & Extra \\
\hline$?$ & Technical Publication \\
\hline
\end{tabular}




\section{EXTERNAL DISTRIBUTION (SPECIAL)}

Number of Copies

4

AEC-RLOO

Attn:

P. G. Holsted

M. R. Keegan

J.H. Sako

Technical Information Library

1

AEC - Washington Military Liaison Committee Attn:

Captain D. E. McCoy, Staff Assistant to the Chairman 
Standard Distribution

ABERDEEN PROVING GROUND

AEROJET-GEAERAL CORPORATION

AEROJET.GEMERAL NUCLEONICS

AERONAUTICAL SYSTEMS DIVISION

AEROPROJECTS INCOR PORATED

AIR FORCE INSTITUTE OF TECHNOLOGY

AIR FORCE IESEARCH AND TECHNOLOGY DIVISION

ALLIS.CHALMERS MANUFACTURING COMPANY

ALLIS.CHALMERS MANUFACTURING COMPANY, BETHESDA

ALLISON DIVISION-GMC

ARGONNE NATIONAL LABORATORY

ARMY ENGINEER RESEARCH AND DEVELOP. MENT LABORATORIES

ARMY BATERIALS RESEARCH AGENCY

ARMY MISSILE COMMAND

ARMY RESEARCH OFFICE, DURHAM

ARMY TANK-AUTOMOTIVE CENTER

ATOMC ENERGY COMMISSIOH, BETHESDA

AEC SCIENTIFIC REPRESENTATIVE, BELGUM

AEC SCIENTIFIC REPRESENTATIVE, FRANCE

AEC SCIENTIFIC REPRESENTATIVE, JAPAN

ATOMIC ENERGY COMAISSION, WASHINGTON

ATOMIC ENERGY OF CANADA LIMITED

ATOMIC ENERGY OF CANADA LIMITED, WHITESHELL

ATOMICS INTERNATIONAL

AVCO CORPORATION

BASCOCK AND WILCOX COMPANY

BATTELLE MEMORIAL INSTITUTE

BEERS (ROLAND F.), INC.

BERYLLIUM CORPORATION

* blume (John a.) AND assocIates

BROORHAVEN NATIONAL LABORATORY

BUREAU OF MINES, ALBANY

SUREAU OF NAYAL WEAPONS
Ptd.
Standard Distribution

BUREAU OF SHIPS (CODE 1500)

CARBORUNDUM COMPANY

CHICAGO PATENT GROUP

COMBUSTION ENGINEERING, INC.

COMBUSTION ENGINEERING, INC. (NRD)

DEFENCE RESEARCH MEMERER

DENVER RESEARCH INSTITUTE

DOW CHEMICAL COMPANY, ROCKY PLATS

DU PONT COMPAKY, AIKEN

DU PONT COMPANY, WLLMIRGTON

FRANKFORD ARSEMAL

FRANKLIN INSTITUTE OF PENMSYLYANIA

FUNDAMENTAL METHODS ASSOCIATION

GENERAL ATOMIC DIVISION

GENERAL DYMAMICS/FORT WORTH

GENERAL ELECTRIC COMPANY, CINCMNATI

GENERAL ELECTRIC COMPANY, PLEASANTON

GENERAL ELECTRIC COMPANY, SAN JOSE

GENERAL NUCLEAR ENGINE ERING CORPORATION

GOODYEAR ATOMIC CORPORATION

IIT RESEARCH INSTITUTE

*INTERNATIONAL BUSINESS MACHINES CORPORATION

IOWA STATE UNIVERSITY

JET PROPULSION LABORATORY

JOHNS MOPKINS UNIVERSITY

KNOLLS ATOMIC POWER LABORATORY

LING TEMCO VOUGHT, INC.

LOCKHEEO-GEORGIA COMPANY

LOCRHEED MISSILES AND SPACE COMPANY (NASA)

LOS ALAMOS SCIENTIFIC LABORATORY

M\& CNUCLEAR, INC.

MALLIHCKRODT CHEMICAL WORKS

MARITIME ADMINISTRATION

MARTIN-MARIETTA CORPORATION

MOUND LABORATORY 


\begin{tabular}{|c|c|}
\hline td. & Standard Distribution \\
\hline 1 & MASA LEWIS RESEARCH CENTER \\
\hline 1 & NASA MANNED SPACECRAFT CENTER \\
\hline 2 & $\begin{array}{l}\text { NASA SCIENTIFIC AND TECHMICAL } \\
\text { INFORMATION FACILITY }\end{array}$ \\
\hline 2 & NATIONAL BUREAU OF STANDARDS \\
\hline 1 & NATIONAL BUREAU OF STANDARDS (LIBRARY) \\
\hline 2 & NATIONAL LEAD COMPANY OF OHO \\
\hline 1 & WAYAL POSTGRADUATE SCHOOL \\
\hline 3 & NAYAL RESEARCH LABORATORY \\
\hline 1 & NRA. INC. \\
\hline 1 & $\begin{array}{l}\text { NUCLEAR MATERIALS AND EQUIPMENT } \\
\text { CORPORATION }\end{array}$ \\
\hline 1 & NUCLEAR METALS, INC. \\
\hline 1 & NUCLEAR UTILITY SERVICES, INC. \\
\hline 1 & $\begin{array}{l}\text { OFFICE OF ASSISTANT GENERAL COUNSEL } \\
\text { FOR PATENTS (AEC) }\end{array}$ \\
\hline 2 & OFFICE OF NAYAL RESEARCH \\
\hline 1 & OFFICE OF NAYAL RESEARCH (CODE 422) \\
\hline 1 & OHIO STATE UNIVERSITY \\
\hline 1 & PETROLEUM CONSULTANTS \\
\hline 4 & PHILLIPS PETROLEUM COMPANY (NRTS) \\
\hline 1 & PHYSICS INTERNATIONAL, INC. \\
\hline 1 & PICATINAY ARSEMAL \\
\hline 1 & POWER REACTOR DEVELOPMENT COMPANY \\
\hline 3 & PRATT AND WHITNEY AIRCRAFT DIVISION \\
\hline 1 & PURDUE UNIVERSITY \\
\hline 1 & RADIOPTICS, INC. \\
\hline 1 & RAND CORPORATION \\
\hline 1 & REACTIVE METALS, INC. \\
\hline 1 & REACTIVE METALS. IHC., ASHTABULA \\
\hline
\end{tabular}

PId.

I
Standard Distribution

RENSSELAER POLYTECHNIC INSTITUTE

SAM FRANCISCO OPERATIONS OFFICE

SANDIA CORPORATION, ALBUQUERQUE

SANDIA CORPORATION, LIVERMORE

SOUTHWEST RESEARCH INSTITUTE

STANFORD UNIVERSITY (SLAC)

SYLVANIA ELECTRIC PRODUCTS, INC.

TENMESSEE VALLEY AUTHORITY

TRW SPACE TECHAOLOGY LABORATORIES (NASA)

UNION CARBIDE CORPORATION, CLEVELANO

UNION CARBIDE CORPORATION (GRGDP)

UMION CARBIDE CORPORATION (ORNL)

UNION CARBIEE CORPORATION (PADUCAH PLANT)

UNITED NUCLEAR CORPORATION (NDA)

U. S. GEOLOGICAL SURVEY, DENVER

U. S. GEOLOGICAL SURYEY, MENLO PARK

U. S. GEOLOGICAL SURVEY, WASHINGTON

U. S. PATENT OFFICE

UNIVERSITY OF CALIPORNIA, BERKELEY

UNIVERSITY OF CALIF ORNIA, LIVERMORE

UNIVERSITY OF PUERTO RICO

WESTERN RESERVE UNIVERSITY (MAJOR)

WESTINGHOUSE BETTIS ATOMIC POWER LABORATORY

WESTINGHOUSE ELECTRIC CORPORATION

WESTINGHOUSE ELECTRIC CORPORATION (MASA)

DIVISION OF TECHNICAL INFORMATION EXTENSION

CLEARINGHOUSE FOR FECERAL SCIENTIFIC AND TECHNICAL IMFORMATION 